\title{
TREKKING TOWARD ÜBER REGULATION: PROSPECTS FOR MEANINGFUL CHANGE AT SEC ENFORCEMENT?
}

\author{
Douglas M. Branson
}

"Once the guardian of the nation's capital markets, known as an efficient regulator with a highly respected enforcement program, the [SEC] is now the subject of much criticism and is mired in scandal." ${ }^{1}$ Ralph Nader, a critic of government regulation in all its forms, once rated the SEC as the best agency in Washington, head and shoulders above any competitor. ${ }^{2}$ Today, those in the securities industry seem to exhibit little fear of the agency and enforcement actions by it. Major scandals (Bernard Madoff, R. Allen Stanford, WestView Capital) go undetected (at least by the SEC) for years or decades, finally unraveling with billions of dollars in investor losses, leaving the SEC only to sweep up and turn out the lights. ${ }^{3}$ It seems each year, one or more major securities-related scandals has unfolded, undeterred in its formative stages by the prospect of SEC action; at full flower, these scandals may be policed and detected by state attorneys general, state securities commissions, or private plaintiffs, but almost never by the SEC. ${ }^{4}$

There now swirl about us countless proposals for regulatory reform. ${ }^{5}$ Certain of the proposals are international, indeed global, in scope. The G-20 meeting, held here in Pittsburgh in September 2009, raised a unified hue and cry by all the participating nations that regulatory actions be taken to avert the near-death experience visited upon economies of the world over in 2008-09. ${ }^{6}$

\footnotetext{
* Condon Falknor Professor of Law, University of Washington; W. Edward Sell Chair in Business Law, University of Pittsburgh.

1. Trends in SEC Enforcement 2009, 41 Sec. Reg. \& L. Rep. (BNA), at 1255 (July 6, 2009) (prepared by Thomas $\mathrm{O}$. Gorman, a highly respected former SEC enforcement attorney).

2. Ralph Nader, The Monopoly Makers: Ralph Nader's Study Group Report on Regulation (Mark J. Green ed., 1973).

3. See, e.g., Kara Scannell, SEC Botched Inquiries into Madoff Scheme, WaLl ST. J., Sept. 3, 2009, at C3 (report of SEC Inspector General David Kotz).

4. See discussion and notes infra Part IV.

5. This is evidenced by law review and other symposia discussing proposals for regulatory reform. See, e.g., Symposium, New Models for Regulating the Financial Markets-The SEC's Future as it Turns 75, U. Cin. L. Rev. (forthcoming 2009); Symposium, New Paradigms for Financial Regulation in the United States and the European Union, BRoOK. L. REv. (forthcoming 2009).

6. Stephen Labaton, Finance Reform 's Middle Ground; Frank's Committee Announces Proposal that Preserves Core of White House Plan but Removes Obstacle, Pittsburgh Post-Gazette, Sept. 24, 2009, at A11.
} 
Every proposal put forward has a common ingredient: an inexorable trend toward bigness. The U.S. government would reach for bigness in at least two ways. One is the merger of existing agencies and commissions, usually to be followed by conflation of the new larger agencies' jurisdictional reach. Second is the creation and empowerment of new über regulators, ${ }^{7}$ exercising oversight over vast sectors of economic activity while perhaps further assuming some front-line responsibilities.

Thus far the SEC has escaped all of this. Early suggestions for a merger of the SEC with the Commodities Futures Trading Commission (CFTC) seem to have faded. ${ }^{8}$ Instead, led by SEC Chair Mary Schapiro, the Commission has undertaken a number of new regulatory initiatives and tried to impart a new tone at the top, particularly in enforcement.

The purpose of this essay is to describe some of these developments, tease out the pros and cons of the march toward bigness, and to evaluate this overall trend. The conclusion? The principal problem is that the SEC has now become the last fire truck to arrive at the scene of the fire, when not too long ago it was leading the charge. Many times the SEC fire truck arrives at the fire not at all. Other times, it arrives, but late and behind the wheel of a dinky little fire truck, ill-equipped to extinguish the fire; limping along in this fashion, the Commission is disrespected further and even ignored by Wall Street, not to mention federal judges. ${ }^{9}$ Nothing in the trend toward bigness, and only tangentially a few items in the SEC program of specific regulatory reforms, addresses the predicament in which the SEC finds itself. How once again to become the first responder, the first fire truck on the scene, respected by all,

7. Über is a German word whose literal meaning is "over" or "above." Collins German DICTIONARY 490 (3d ed. 1998) (reprint 2001). In German, über ineffably connotes superiority and perhaps dominance as well. Deutschland Über Alles is the German national anthem.

8. See SEC Must Remain Independent, State Pension Funds Urge Geithner, 41 Sec. Reg. \& L. Rep. (BNA), at 1007 (June 1, 2009).

9. In a $\$ 3.6$ billion bonus case, the SEC had charged Bank of America (BofA) with a misleading proxy disclosure when BofA sought shareholder approval of the acquisition of Merrill Lynch. BofA led shareholders to believe that Merrill would not pay bonuses when, in fact, it had already paid billions. The SEC named no individuals as defendants, accepted a nolo contendere plea from BofA, and proposed a mild $\$ 33$ million settlement (the dinky fire truck). Federal District Court Judge Jed Rakoff rejected the SEC's proffered settlement, finding that the very shareholders who had been misled would pay the settlement and that the proposed settlement "does not comport with even the most elementary notions of justice and morality." Kara Scannell, Liz Rappaport \& Jess Bravin, Judge Tosses Out Bonus Deal, Wall St. J., Sept. 15, 2009, at A1; Editorial, Rakoff Rakes the SEC, WALL ST. J., Sept. 15, 2009, at A20. The episode "puts new pressure on the agency to show that it is fighting for investors ...." Scannell, supra. To some it was indicative of worse than a lack of fight: "That doesn't restore your reputation very well. They were hoping to slip a quick and dirty settlement past the judge and got called on it." Kara Scannell, BofA Ruling Questions an SEC Weapon, WALl St. J., Sept. 16, 2009, at C3 (comment of Professor Peter Henning). 
admired by some, feared by many, and able once again to gain the confidence of the public and to project a level of deterrence that will put an end to the greed and recklessness that has characterized this decade?

\section{The Proposals}

\section{A. The Proposed Paulson Reforms}

Hank Paulson, former CEO of the large and highly profitable financial services firm Goldman Sachs, served as Secretary of the Treasury under President George W. Bush. In March 2008, Secretary Paulson fired the first salvo, publishing a white paper that promoted the Federal Reserve as an $\ddot{u} b e r$ regulator, "in effect allowing it to send SWAT teams into any corner of the industry or institution that might pose a risk to the overall system." ${ }^{10}$ The Bush administration said that "the Federal Reserve should be given sweeping new powers to protect the integrity of the financial system, contending that market turmoil had exposed a badly outdated regulatory system."11 More recently, Citigroup founder Sanford Weill floated a very similar proposal: "Make the Federal Reserve the super-regulator responsible for overseeing systemic risk. It is vital that one regulator be able to see the entire balance sheet of the country's largest financial institutions. . . Large banks, securities firms, insurers and hedge funds should all come under the Fed's aegis." 12

\section{B. Ex-SEC Chairman Harvey Pitt's Views}

Chairman Pitt took to the hustings in early 2009, offering views that the existing regulatory system is "badly broken" and that "an extensive overhaul is in order." 13 According to the Chairman, repairing the regulatory system in the area of finance is "critical and necessary." In 1998-99, when Congress had

10. Edmund L. Andrews, Treasury's Plan Would Give Fed Wide New Power, N.Y. Times, Mar. 29, 2008, at Al. See also Press Release, U.S. Dept. of the Treasury, Treasury Releases Blueprint for Stronger Regulatory Structure (Mar. 31, 2008) ("The U.S. regulatory structure does not serve America as well as it could, and modernization is inevitable.").

11. Associated Press, Treasury Secretary Requests Greater Powers for the Federal Reserve, N.Y. Times, June 20, 2008, at C3.

12. Sanford I. Weill \& Judah S. Kraushaar, Six Steps to Revitalize the Financial System, WALL ST. J., Oct. 26, 2009, at A19.

13. Harvey Pitt, Former Chairman, SEC, Address at the University of Dayton School of Law Symposium: The Fallout from the Bailout: The Impact of the 2008 Bailout on Lending Regulation, Securities Regulation and Business Ethics (Mar. 20, 2009). 
an opportunity to do so, Congress did not modernize the regulatory patchwork. In enacting the Gramm-Leach-Bliley Act, Congress rescinded the GlassSteagall Act, permitting commercial banks headlong entry into a financial arena occupied by investment banks; at the same time, though, Congress failed to fill in any of the crevices, such as regulation of new derivative products and synthetic derivatives, ${ }^{14}$ and in fact forbade the SEC to regulate in those areas. As a result, while banks could offer one-stop shopping across a broad and expanding array of financial products and services, regulation remained a "patchwork" consisting of various agencies regulating various areas, with many areas not regulated at all. Chairman Pitt's guidelines for regulatory reform included:

- The SEC must revamp its compliance surveillance.

- Government must enhance its risk management capabilities in all financial areas.

- Government has to ensure that regulatory agencies have the authority and the responsibility to regulate all new financial products.

The best way to achieve these aims? The President and the Congress should create an über regulator so that no cracks or crevices would exist any longer.

\section{President Obama's Proposals}

When they emerged, the Administration's proposals pulled the punch that had been anticipated. No merger of the SEC and other agencies, such as the CFTC, would occur. No full-blown über regulator would emerge. Instead, a front-line regulator, the Federal Reserve, would assume overall supervision, presumably including risk management, for large financial firms (Tier 1 Financial Holding Companies, or FHCs) of whatever stripe (commercial banks, investment banks, brokerage firms). ${ }^{15}$ The Office of Thrift Supervision (formerly the Federal Home Loan Bank Board) would cease to exist, merging with the Office of the Comptroller of the Currency (an agency within Treasury which regulates national banks) to form the first of two partial über regulators (some über, some front-line responsibility), the National Bank Supervisor. A second partial über regulator, the Commercial Financial Protection Agency,

14. See Caiola v. Citibank, N.A., N.Y., 295 F.3d 312 (2d Cir. 2002) (describing synthetics generally).

15. Administration Regulatory Overhaul Would Concentrate Many New Powers at Fed, 41 Sec. Reg. \& L. Rep. (BNA), at 1137 (June 22, 2009) [hereinafter Regulatory Overhaul]. During the financial meltdown, of course, many formerly financial firms such as Morgan Stanley and Goldman Sachs had become banks so that they could have access to borrowings from the Federal Reserve. 
would assume oversight over issuance of and collections on credit cards, mortgage banking, and similar affairs. ${ }^{16}$ Last of all, a Financial Services Oversight Council, chaired by the Secretary of Treasury and with its own fulltime staff within Treasury, would preside. Membership would include the chiefs of the financial regulatory agencies (SEC, CFTC, the Federal Deposit Insurance Corporation (FDIC), the Federal Housing Finance Agency, the new National Bank Supervisor, and the new Consumer Financial Protection Agency). Among its principal tasks, the Council would designate which firms ought to be classified as Tier 1 FHCs and thus subject to Federal Reserve oversight. ${ }^{17}$

The SEC actually emerged with expanded powers, including recommendations that the SEC have power to impose fiduciary as well as suitability standards on brokers, serve as the conservator or receiver when the largest subsidiary of a failing financial firm is a broker-dealer or securities firm, and give expanded protection to whistle-blowers in the financial field. ${ }^{18}$

Matter-of-fact appraisals portrayed the Administration as "backing away from seeking a major reduction in the number of agencies overseeing the financial markets .... [Administration officials now] expect to call for most existing agencies to have broader powers . ..."19 Rather than creating new larger regulators and an additional layer of oversight, officials sought to "fill gaps between agencies and eliminate overlaps. ${ }^{.20}$ Experienced pundits termed

16. The new "agency would monitor the fine print on such products as credit cards and mortgages. Such oversight is now scattered." Anne Flaherty, Geithner: Oversight in Need of Reform, PITTSBURGH Post-Gazette, July 25, 2009, at A7. Under the Obama proposal, the new agency would also dictate terms for "plain vanilla" versions of those items, such as 30 -year mortgages and low-interest, low-fee credit cards. Republicans argued that such a legislative feature was "the first step toward having government bureaucrats approve and disapprove an array of products." The Obama proponents withdrew that feature of the proposed legislation. Labaton, supra note 6.

17. Regulatory Overhaul, supra note 15, at 1138. Presaging his Administration's proposals, President Obama had stated earlier his guiding principles for reform:

Citing "turmoil on Wall Street like we haven't seen in decades," Obama called for "clear rules of the road ... to protect consumers and investors and ultimately to keep those financial institutions strong." He listed seven principles to guide Congress in planning a new financial regulatory framework: serious oversight to prevent systemic risk, reform of the regulatory structure, transparency, uniform supervision of financial products, accountability, comprehensiveness, and recognition of the global nature of the challenge.

Obama Lists Key Principles for Reform of Nation's Financial Regulatory System, 41 Sec. Reg. \& L. Rep. (BNA), at 335 (Mar. 2, 2009).

18. See, e.g., Administration Sees Expanded SEC Role in Proposed Financial Regulatory Regime, 41 Sec. Reg. \& L. Rep. (BNA), at 1139 (June 22, 2009).

19. Damian Paletta, Finance Reforms Pared Back, WAll St. J., June 9, 2009, at A1.

20. Id. at A4. 
the SEC "a winner" in the Administration proposals, which praised the SEC as "an experienced federal supervisor." 21

\section{Senator Dodd and Related Proposals}

A commercial bank, or its equivalent, may be regulated by the Comptroller of the Currency, the Federal Reserve, the Federal Deposit Insurance Corporation, the Office of Thrift Supervision, or a state Department of Banking or Department of Financial Institutions. Startup organizations could and did seek out the cracks and crevices in the system so as to escape regulatory oversight. "It never made sense that a credit-card product offered by Chase was overseen by one regulator according to one set of standards, while a virtually identical product offered by a competitor would be overseen by a completely different regulator according to different standards."22

So the push for an über regulator, or at least one for banks, re-emerged. ${ }^{23}$ All institutions, "wherever they're regulated," including "sectors of the financial system that have long fallen outside the scope of any agency," will come under one large banking agency. In the Congress, the über banking regulator's standard-bearer became Senator Christopher Dodd, who chairs the Senate Banking Committee and who introduced legislation to roll the Comptroller of the Currency, Office of Thrift Supervision, FDIC, and Federal Reserve into one. ${ }^{24} \mathrm{Mr}$. Dodd says that "the market crisis last year was caused in part by banks that were able to choose which agency would regulate them and by bank agencies that reduced regulations to encourage more banks to choose them." 25 Über appeared to be becoming über once again.

The Dodd plan is likely to receive sharp resistance from banking industry lobbyists who wish to preserve as much of the current system as they can and

21. Securities Regulation under the Obama Plan, 41 Sec. Reg. \& L. Rep. (BNA), at 1209 (June 29, 2009) [hereinafter Obama Plan] (Prepared by Stephen J. Crimmins, a former high-level SEC enforcement and trial attorney).

22. Jamie Dimon, A Unified Bank Regulator Is a Good Start, WaLl St. J., June 27, 2009, at A13 (Mr. Dimon is Chairperson and Chief Executive Officer of J.P. Morgan Chase \& Co.).

23. A push for an über regulator for investments reemerged as well, with SEC Commissioner Luis Aguilar's advocacy of a merger of the SEC, the Commodities Futures Trading Commission (CFTC), and the Employment Retirement Income Security Act of 1974 functions of the Department of Labor. The latter currently are performed by the Employee Benefits Security Administration within the Department of Labor. See Aguilar Expressly Supports Single Regulator, Urges SEC, CTFC to Combine with DOL Entity, $41 \mathrm{Sec}$. Reg. \& L. Rep. (BNA), at 1053 (June 8, 2009).

24. Stephen Labaton, Leading Senator Pushes New Plan to Oversee Banks, N.Y. Times, Sept. 20, 2009 , at A1.

25. Id. 
with it the advantages for regulatory arbitrage, which at the extreme critics dub "the race for the bottom." The Dodd plan would provide for a consumer financial protection agency, as would the Obama plan, but would significantly reduce the Federal Reserve's role. ${ }^{26}$

\section{E. Big on Big Proposals}

Certain knowledgeable observers take these proposals several steps further, advocating bigness for bigness's sake. We need big tough regulators to take on the bigger, ofttimes incorrigible financial institutions, some of which have grown to gargantuan size:

[T] he assets of the nation's security brokers and dealers increased from $\$ 45$ billion (1.6 percent of gross domestic product) in 1980 to $\$ 262$ billion (4.5 percent of GDP) in 1990 to more than $\$ 3$ trillion (22 percent of GDP) in 2007. [B] ear Stearns saw its assets increase from about $\$ 37$ billion in 1999 to nearly $\$ 400$ billion at the start of 2007; and the behemoth Citigroup . . grew its balance sheet from less than $\$ 700$ billion at the start of 1999 to more than $\$ 2$ trillion by 2007! The rise of massive institutions represented a profound change in our financial system and a powerful new source of systemic risk. Yet we didn't update our regulatory policies in response $\ldots .^{27}$

\section{F. Chairman Frank Arrives on the Scene}

Representative Barney Frank, as Chair of the House Financial Services Committee, has concentrated on the trading and regulation of derivative products. The Obama administration wanted all derivatives, which in the financial crisis resulted in the concentration rather than the hedging of risk, to be traded on an exchange or a recognized electronic trading platform. Financial institutions say that certain financial products are not widely traded enough to be on exchanges; many of these products are essential to the management of risk by these front-line firms. In response, Representative Frank has written legislation softening the mandate that products be standardized and traded on exchanges. Officials at the SEC and the CFTC

26. Senator Dodd and the senior Republican Senator, Richard Shelby, "agree generally . . . on skepticism of a more powerful Federal Reserve, reflecting a view widely held by lawmakers." $I d$. Under the Dodd proposal, the Fed would lose authority over banks, its ability to regulate mortgages and credit cards, and a leading role as the über regulator of systemic risk which the Obama administration had planned for it. $I d$.

27. David A. Moss, An Ounce of Prevention: Financial Regulation, Moral Hazard, and the End of "Too Big to Fail," Harvard Mag., Sept.-Oct. 2009, 25, 26-27 (According to Moss, "the biggest culprits of all were the supersized financial institutions."). 
reacted by publicly stating that Chairman Frank's carve-outs are too generous. ${ }^{28}$

\section{G. International Developments}

The European Union Commission has completed draft legislation that would provide for a pan-European über regulator. The European Systemic Risk Board would be charged with detection of risks in the financial systems of 27 countries, issuing warnings and prescriptions for corrective actions. ${ }^{29}$ G-20 leaders discussed "how to get banks to fatten their capital cushions and limit leverage of that capital," seemingly sounding a prelude for yet another über regulator proposal. ${ }^{30}$

\section{ON Bigness}

\section{A. Progress}

Thus far, proposals for a hydra-headed über regulator have made little progress. This has led to reports of tantrums by the Treasury Secretary: "Secretary Timothy Geithner blasted top U.S. financial regulators in an expletive-laced critique last Friday as frustration grows over the Obama administration's faltering plan to overhaul U.S. financial regulation . ..."31 What seems to hamstring the proposals' progress is the difficulty of reaching around them or, indeed, even around several of the regulatory agencies being proposed. In that sense, "big" may be a disadvantage.

28. Sarah N. Lynch, Frank's Plan Criticized as Too Lax, WALL ST. J., Oct. 8, 2009, at C3; CTFC's Gensler and SEC's Hu Highlight Potential Thorns in Frank's Derivatives Draft, 41 Sec. Reg. \& L. Rep. (BNA), at 1856 (Oct. 12, 2009).

29. Len Boselovic \& Elwin Green, G-20 Leaders Eager to Regulate Banking Executives' Pay, Pittsburgh Post-Gazette, Sept. 25, 2009, at A4.

30. Cindy Skrzycki, G-20 Leaders Likely to Fault Sluggish Financial Reform in U.S., PITTSBURGH Post-Gazette, Sept. 25, 2009, at A6.

31. Damian Paletta \& Deborah Solomon, Geithner Vents as Overhaul Stumbles, WaLl St. J., Aug. 4, 2009, at A1. 
B. The Advantages of Big

1. Meet Force with like Force: Big Institutions Need Big Powerful Regulators

A global trend exists toward bigness. Multinational corporations strive to be number one, two or perhaps three in their core competencies, not on a regional, national or pan-national (European Union or similar) scale, but on a global basis. ${ }^{32}$ The Microsoft antitrust case is instructive. Microsoft used its monopoly over the basic operating system (Windows) to force original equipment manufacturers (OEMs) to install Microsoft's web browser, Explorer, rather than the first widely used browser by Netscape. Often using bare knuckles, Microsoft rapidly went from 3 to 97 percent domestic market share.

For an antitrust violation to exist, the would-be violator must have a monopoly on the tying product, here the basic system. Whether they have a monopoly depends upon how the relevant geographic market is defined. If the market is only a national one (300 million persons), Microsoft probably engaged in an illicit practice. ${ }^{33}$ On the other hand, if the market is a global one (6.3 billion persons), Microsoft must engage in some of these practices if it is to compete on the world stage. "Think Global," "Get Big Fast," "The Earth Is Flat." Why should regulatory agencies be any different?

2. With Big Über Regulators, Gaps or Crevices No Longer Exist, So Opportunities for Regulatory Arbitrage Are Minimized, or Eliminated Altogether

With one big regulator over commercial and investment banks, "[i]nstitutions aren't going to be able to play one regulator off against another the way they have in the past." ${ }^{" 34}$ In fact, certain of the players, such as Washington Mutual and Countrywide Mortgage, have "flipped their charters to escape regulation by the Fed" and, in certain instances, any meaningful regulation at all. "The new empowerment of the Fed will bring the U.S. more

32. See, e.g., Douglas M. Branson, The Very Uncertain Prospect of Global Convergence in Corporate Governance, 34 CORNELL INT'L L.J. 321, 352-56 (2001).

33. See, e.g., Charles Forelle, Microsoft Yields to EU on Web Browsers, WALL ST. J., July 25, 2009, at B1.

34. Interview with Larry H. Summers, Chair, President's National Economic Council, in Maria Bartiromo, Facetime: Summers on Obama's New Financial Regulations, Bus. WK., July 6, 2009, at 8. 
into line with international practice, where there is a holistic regulator with overall responsibility for the systemic risk posed by institutions." 35

\section{The Disadvantages of Big}

1. If Big Is So Necessary to Counter and Confront Big Banks and Big Financial Institutions, Why Do the Big Players Seem Unperturbed by (Indeed Welcoming of) Bigness and the Über Regulator?

Secretary of the Treasury Timothy Geithner is seen as a leading advocate of "the Wall Street-centric view." ${ }^{36} \mathrm{He}$ unabashedly has promoted bank mergers, use of TARP funds for big banks to make acquisitions of other banks, getting bigger (our nation, according to Secretary Geithner, is "over banked"), and imposition of an über regulator. "Our system failed in basic fundamental ways .... [T] address this will require comprehensive reform. Not modest reform at the margin, but new rules of the game." ${ }^{.37}$

It appears that big institutions receive lighter treatment from big and powerful regulators. It is the small guy and the mid-size person who get steamrollered by the big, bureaucratic regulator. Wall Street institutions know this. Besides, big regulators can provide them with big infusions of capital. Citigroup received $\$ 45$ billion. Bank of America also received $\$ 45$ billion in bailout funds. ${ }^{38}$ The large institutions, and those who speak on their behalf, welcome bigger über type regulators or, at least, the status quo. "[E]xchanges and clearing houses should be allowed to choose their regulator," one exchange CEO maintained. ${ }^{39}$

\section{Big Would Result in Great Losses of Morale and Esprit De Corps}

Possession of dedication, loyalty, and a capacity for hard work that exceeds that of the staff at any other Washington agency, bar none, has always

35. Id.

36. Ryan Lizza, The Contrarian; Sheila Blair and the White House Financial Debate, THE New Yorker, July 6, 2009, 30, 30.

37. John Cassidy, Rational Irrationality; The Real Reason that Capitalism is so Crash-Prone, THE New Yorker, Oct. 5, 2009, 30, 34.

38. See, e.g., Editorial, Troubled Banks, Huge Bonuses, N.Y. Times, Aug. 3, 2009, at A20 (receiving $\$ 45$ billion each, Citigroup paid out $\$ 5.33$ billion in bonuses to employees while Bank of America paid out $\$ 3.3$ billion).

39. Kara Scannell, Exchanges Offer Varying Views as Regulators Discuss Turf, WaLl ST. J., Sept. 3, 2009, at C3 (remarks of CME CEO Craig Donahue). 
been a hallmark of the SEC. As 5:00 p.m. approaches, most government agencies empty faster than a grammar school on a spring day. At the SEC, as 6:30 p.m. or even 7:00 p.m. approaches, half the staff is still working at their desks. Traditionally, at least, SEC rank-and-file have fervor for what they do. That fervor, dedication, loyalty, and esprit de corps, what some have termed part of "the DNA of the agency," 40 would be lost should the SEC be consolidated with other agencies. ${ }^{41}$ On information and belief, the CFTC, which is a smaller agency yet, has a reputation for having high levels of morale and fervor.

In all of this quest for reform, no person in authority has raised even the possibility that mergers and the formation of an über regulator may entail lasting and significant intangible costs in terms of loss of spirit and morale.

\section{Big Regulators Produce Large Quantities of Vapid and Turgid "Bloat"}

The SEC is already infected with this problem. In days of yore, as a small and efficient agency, the Commission promulgated three and five-page releases. They left numerous "fruitful ambiguities," to be worked out over time, or not worked out at all.

Things have changed. One recent release, on possible adoption of a modified uptick rule applicable to short selling, contained 243 pages, replete with 266 footnotes. ${ }^{42} \mathrm{~A}$ follow-on release, requiring broker-dealers to close fails to deliver, mainly by short-selling clients, had 100 pages. ${ }^{43}$ Following adoption of the Sarbanes-Oxley Act, which required that at least one member of a public company's audit committee be a "financial expert," the SEC devoted a 63-page release to this relatively simple topic, when two or three pages surely would have sufficed. ${ }^{44}$ In lengthening its pronouncements, the SEC is substituting plain ambiguity for fruitful ambiguity, largely a

40. See, e.g., Jonathan G. Katz, Reviewing the SEC, Reinvigorating the SEC, 71 U. PITT. L. Rev. 489 (2010).

41. The SEC is a surprisingly small agency. As of June 1, 2009 the Commission had 3,652 staff. Its fiscal year 2010 request was for $\$ 1,026$ million and its 2011 request was $\$ 1,241$ million. Its staff size is much smaller than, say, the FDIC, which has more than 5,000 employees. SEC Seeks Significant Increase in Funding for FY 2010, 2011, Citing Staffing Shortage, 41 Sec. Reg. \& L. Rep. (BNA), at 1049 (June 8, 2009).

42. Amendments to Regulation SHO, Exchange Act Release No. 34-59748 (Apr. 10, 2009) (modified uptick rule release).

43. Amendments to Regulation SHO, Exchange Act Release No. 34-60388 (July 27, 2009) (fail to deliver release).

44. Disclosure Required by Sections 406 and 407 of the Sarbanes-Oxley Act of 2002, Exchange Act Release Nos. 33-8177, 34-47235 (Mar. 3, 2003). 
counterproductive effort. Much more of the same will come with big über regulators.

4. Existence off Big Über Regulators Will Conflate the Expectations Gap, Already Too Big as it Is

Politicians today do not stand up and declare that government cannot solve this problem, or that problem, or all problems. They lead the citizenry to believe that government can be all things to all people. So do regulators. So does the mere existence of large and, inferentially, all-powerful regulatory agencies. ${ }^{45}$ Among the myriad proposals for $\ddot{u} b e r$ regulators in the financial area, " $t$ the biggest danger of a Consumer Financial Protection Agency is ... that giving products a government imprimatur can make people feel safer than they really are. (The economist Kip Viscusi has termed this type of problem the 'lulling effect.')." ${ }^{.46}$ But it is worse than that. Instead of lulling, the creation of a big, supposedly all-powerful agency creates affirmative expectations that government can bail anyone out of almost any problem. Rather than a new regulator, "it would do well to teach consumers a simple lesson: if you don't understand the deal you're making, don't make it." ${ }^{\prime 4}$

\section{If Big Is Not the Answer, Are Discrete Improvements TO ENFORCEMENT?}

\section{A. No Über Regulator}

SEC Chair Mary Schapiro warned the Senate Banking Committee "not to create a monolithic regulator threatening the authority of her agency and its mandate over the capital markets." ${ }^{48}$ Her comments were heard. As has been seen, ${ }^{49}$ none of the many and widely differing über regulator proposals

\footnotetext{
45. "The expectations gap is real: securities regulation is far from any assurance of corporate transparency, delivering neither as much protection as many investors assume nor as much as is optimal." Donald C. Langevoort, Managing the "Expectations Gap" in Investor Protection: The SEC and the PostEnron Reform Agenda, 48 VILL. L. REV. 1139, 1140 (2003). "New rules that are not enforced effectively become part of the problem - they exacerbate the gap, rather than help reduce it." Id. at 1164. So, too, big new agencies, whose power and capability does not match appearances, exacerbate the gap.

46. James Surowiecki, Caveat Mortgagor, The New Yorker, July 6, 2009, at 28.

47. Id.

48. Witnesses Testify to Regulatory Gaps; Schapiro Warns of "Monolithic Regulator, "41 Sec. Reg. \& L. Rep. (BNA), at 549 (Mar. 30, 2009).

49. See supra Part I discussion and notes.
} 
included the SEC. Instead, " $[t]$ he Securities and Exchange Commission clearly has the Administration's confidence and appears a winner in the opening phase of the financial services regulatory reorganization," one commentator said as a prelude to his observations. He continued: "[t]he Treasury proposal now praises the SEC as 'an experienced federal supervisor' and ... assigns it substantial new responsibilities." ${ }^{, 50}$ Thus, for the time being, the SEC can put back into the closet the prospect of an über regulator towering over or absorbing the Commission. Accordingly, the time has come to examine closely the assignment to the Commission of "substantial new responsibilities" as well as the refurbishment of some old ones.

\section{B. Initiatives by or for the SEC}

The Obama administration wants all standardized derivatives to be traded on exchanges or cleared through the mechanisms of electronic trading platforms where they would be subject to robust margin and record-keeping requirements. ${ }^{51}$ Presently, such transactions often go unreported, even to the extent of taking place in back rooms. As part of the Administration's proposals, the Treasury wants to require that hedge funds and private equity firms register with the SEC pursuant to the Investment Advisers Act. ${ }^{52}$ Closer to enforcement, the proposed Treasury reforms would require the classification of registered representatives as fiduciaries in all cases, not merely when the broker had held herself out as being such..$^{53}$ The SEC could in effect (by a four out of five commissioner vote) put broker-dealer subsidiaries of large financial firms into involuntary "resolution" proceedings in which the SEC would be the conservator or receiver. ${ }^{54}$ Another plank in the new platform would involve revoking the 10-day rule, under which brokerdealers could vote "street name" shares if beneficial owners had failed to vote, in part on the grounds that brokers never properly analyzed the issues, blindly

50. Obama Plan, supra note 21, at 1209.

51. Id. at 1210 .

52. $I d$.

53. Id. at 1211. Of course, a great, although perhaps not insurmountable, inconsistency exists between the broker-dealer's traditional role as a salesperson and role as a fiduciary, with duties of the utmost good faith and loyalty. See generally Donald C. Langevoort, Brokers as Fiduciaries, 71 U. PITT. L. REv. 439 (2010).

54. Obama Plan, supra note 21, at 1211. The SEC had already reversed itself on the near polar opposite, namely, no supervision or light supervision of large diversified financial firms. In Fall 2008, after the failures and near failures of Lehman Brothers, Bear Stearns, and Merrill Lynch, the SEC terminated its voluntary supervision (supervision lite) program for "consolidated supervised entities" (CSEs). Id. 
voting with corporate management in most cases. ${ }^{55}$ These and other proposed reforms would widen and deepen SEC jurisdiction but they only impinge upon enforcement. Strictly speaking, these reforms would be adjuncts to enforcement rather than enforcement itself.

\section{Reforms to Bring Back "A Sense of Urgency” to SEC Enforcement ${ }^{56}$}

SEC Chair Mary Schapiro wants to put in place a number of measures that will make the agency's enforcement staff "more fleet-footed." ${ }^{17}$ Steps the SEC has taken or proposes to take include the following: ${ }^{.8}$

- Returning Subpoena Power to the Staff from the Commission. Under Chairman Christopher Cox, attorneys had to seek authority from the full Commission before being able to sign and serve official discovery requests. The resulting delay caused considerable down time, or even dead time, in securities fraud investigations or other proceedings. One of Commission Chair Mary Schapiro's first reforms was to abolish the practice. ${ }^{59}$

- Eliminating Extensions of Time for Wells Submissions. A would-be defendant who has been a party to an SEC investigation is given a formal opportunity to present its side of the case, showing why it should not be sued. "The process will tighten up by quite a bit" under the new regime. ${ }^{60}$ No extensions of time will be granted to putative defendants and their attorneys.

- Seeking the Authority to Be Able to Pay Bounties to Whistle Blowers. Presently, the SEC may only pay bounties, limited to 10 percent, in insider trading cases. Chair Mary Schapiro wants to broaden the Commission's authority considerably. ${ }^{61}$ The SEC

55. Sarah Lynch, SEC Plan Aims to Better Foretell Risks, WALL ST. J., July 2, 2009, at C3.

56. Kara Scannell, "Urgency" Drives SEC Crackdown, Wall St. J., Aug. 11, 2009, at C1 (reporting comments of new SEC enforcement chief Robert Khuzami).

57. $I d$.

58. These and other steps to bolster enforcement are also reviewed in detail by Professor Jayne Barnard. See generally Jayne Barnard, Evolutionary Enforcement at the Securities and Exchange Commission, 71 U. Pitt. L. Rev. 403 ( 2010).

59. See, e.g., The SEC's Blueprint to Reinvigorate Enforcement, 41 Fed. Sec. Reg. \& L. Rep. (BNA), at 671 (Apr. 13, 2009) [hereinafter Blueprint] (presently the duty officer or commissioners in seriatim may authorize a formal order allowing staff to use the agency's subpoena power).

60. Enforcement Division to Tighten Processes; Penalty Guidance, Manual are Under Review, 41 Fed. Sec. Reg. \& L. Rep. (BNA), at 805 (May 4, 2009).

61. See Blueprint, supra note 59, at 669 (paraphrasing testimony of Chairperson Schapiro before the House Committee on Appropriations and the Senate Committee on Banking, Housing and Urban 
program would model itself after the Internal Revenue Service (IRS) program, authorized by the Tax Relief and Health Care Act of 2006. Under the program, the IRS may pay whistle-blowers from 15 to 30 percent of the amount the IRS has recovered. ${ }^{62}$

- Obtaining Collateral Bars That Would Foreclose to Wrongdoing Professionals All Aspects of the Securities Business. Under the existing scheme, SEC attorneys may obtain bar orders against securities professionals only in those business areas in which those professionals have been engaged (for example, a bar as to brokerdealer activity would not bar future affiliation with an investment adviser or a private equity firm). ${ }^{63}$ The Administration proposal is for legislation granting the SEC authority to seek broader bars. ${ }^{64}$

- Forming Specialized Investigative and Litigation Teams Within the Enforcement Division. There are now five units with specialized responsibilities for the following areas:

1. Asset Management Companies.

2. Market Abuse (including insider trading).

3. Structured and New Products (such as credit default swaps).

4. Bribery of Foreign Officials.

5. Municipal Securities and Public Pension Fund Wrongdoing (including "pay-to-play" allegations). ${ }^{65}$

Allocation of staff to preexisting teams, with resources pre-allocated to them, will make for much quicker response times.

- Granting the SEC Staff Authority to Negotiate Civil Penalties without First Obtaining Commission Authorization. SEC-levied civil penalties had grown to $\$ 800$ million in 2003. Then-SEC Chair Christopher Cox instituted a policy that staff would have to seek

Affairs).

62. See Arden Dale, Tax Whistle-Blowers Await Big Pay Day, Wall St. J., Oct. 14. 2009, at B5 (noting that in 2008 the IRS received 476 submissions, blowing the whistle on 1,246 taxpayers, but that under the program overall, after three years no whistle-blower had yet to receive a cent). Another complicating factor is that the SEC receives approximately 700,000 tips and referrals per year. See Blueprint, supra note 59, at 669 .

63. Teicher v. SEC, 177 F.3d 1016 (D.C. Cir. 1999), holds that the SEC had no authority to seek wider bar orders. Previously, the Commission had tried to erect such bars. See Matter of Westerfield, Exchange Act Release No. 34, 41126, 54 SEC Docket 25 (Mar. 1, 1999).

64. See Obama Plan, supra note 21, at 1212.

65. Kara Scannell, SEC to Give Attorneys More Power, WALl St. J., Aug. 6, 2009, at C3; Khuzami Cites Move to Specialized Teams, Other Initiatives to Improve SEC Enforcement, $41 \mathrm{Fed}$. Sec. Reg. \& L. Rep. (BNA), at 849 (May 11, 2009). 
from the full Commission a range, or a collar around, possible penalties before the staff could enter into negotiations with a wrongdoer. Thereafter, penalties dropped precipitously to: $\$ 637$ million in 2006, \$310 million in 2007, and \$96 million in 2008. SEC Chairperson Schapiro revoked the Cox policy: SEC staff can enter into negotiations straightaway, without a detour to consult with commissioners. ${ }^{66}$

These then are certain of the actions taken or proposed to make the SEC quicker on its feet, able to react, and even be proactive in a greater number of cases and matters. They are all laudatory. Many go to reducing reaction time, which had become sclerotic under previous administrations, with restraints placed on enforcement as matters of political expediency. But do they attempt resolution, head-on, of the principal ailment which bedevils securities law enforcement?

\section{The Principal Problem and Evidence of It}

A view widely held is that SEC enforcement peaked in the Shad/Ruder/Breeden era of the late 1980s and early 1990s. ${ }^{67}$ Statistics, which abound and seem to signal renewed vigor at enforcement, do not tell the real story. ${ }^{68}$ That story is that since the early 1990 s SEC enforcement has lost much or, indeed, most of its in terrorem (deterrent) effect. Short of a broadbased attitudinal study, and perhaps not even then, direct evidence cannot be gathered.

Indirect evidence, however, is plentiful. The evidence shows that in this new century major securities scandals unfold each and every year, sometimes two or three times per year. This never happened in the Twentieth Century.

66. See Back to the Future: Chairman Schapiro Ends Pilot Program for Corporate Penalties, Eliminates Commission Pre-authorization, Allows Staff to Negotiate, 41 Fed. Sec. Reg. \& L. Rep. (BNA), at 307 (Feb. 23, 2009).

67. See, e.g., Langevoort, supra note 45, at 1142 (the SEC hit "its apotheosis in the campaign against Wall Street insiders like Ivan Boesky and Michael Milken").

68. In 2008, the SEC Enforcement Division brought 671 enforcement actions, its second highest total on record. The highest total was 679 in 2003, ballooned by financial reporting scandals following Enron and WorldCom. Insider trading prosecutions increased 25 percent and market manipulation cases 45 percent, albeit from a very small number. In particular, the SEC trumpeted its settlements with the largest financial services firms in the auction rate securities cases. FY '08 Saw 671 Enforcement Actions, SEC Reports; Is Second Highest Number, 40 Fed. Sec. Reg. \& L. Rep. (BNA), at 1751 (Oct. 27, 2008). These statistics came from a draft of the SEC's annual Performance and Accountability Review, which it has published each November since 2004. 
There seems to be no effective curb on greed, indeed, unbridled greed. Some of those scandals, and the reactions to them, include:

- The late-day trading and stale price arbitrage scandals of the mutual fund industry. These abuses involved investment companies allowing favored investors, many of which were hedge funds, to enter buy and sell orders after computation of the net asset value (NAV) and the close of business each day. The Massachusetts Attorney General and Securities Commissioner, and not the SEC, played a leading role in discovering these frauds that involved, among others, Putnam Funds, headquartered in the Bay State.

- Research analysts-underwriter conflicts of interest. In days gone by, securities firm research analysts earned adequate but relatively modest wages. When Wall Street hype of individual stocks, including many technology stocks, reached new heights, investment bankers (underwriters) discovered how influential a "buy" or a "strong buy" rating from the firms' analysts could be. The investment bankers began raising the profiles and salaries of research analysts, particularly influential ones such as Mary Meeker or Jack Grubman. Grubman actually attended WorldCom board of directors meetings. He ratcheted up AT\&T's research rating in return for AT\&T CEO Michael Armstrong's efforts in gaining admission of Grubman's twin sons into an elite New York elementary school.

Ultimately, the SEC extracted a $\$ 1.4$ billion settlement from 10 leading securities firms but the initial charge was led by the thenNew York Attorney General Eliot Spitzer. The SEC rode on the last, or next-to-last, fire truck.

- Enron, WorldCom and the corporate governance scandals of 2001-02. In the New Yorker, post-Enron, a reviewer pointed out that in the periodic reports it had filed with the SEC, Enron had made a complete disclosure of every transaction and step Enron undertook, albeit in 8-point type, in 50 or so pages of footnotes, buried at the end of financial statements. ${ }^{69}$ Those revelations added to ammunition with which critics maintained that the SEC should have detected Enron, WorldCom, and similar accounting and governance frauds at an early point. Of course, traditional securities regulation has never expected that the SEC would examine and analyze every document corporations file with the agency. Instead, the mass of company 
periodic report filings constitute a repository that analysts, market letter authors, and so on, read, digest, analyze, and filter out to a wider public. Nonetheless, public and many professional understandings were otherwise. Why didn't the SEC catch it? The SEC had the filings in its possession; the agency could have reviewed them. The corporate governance scandals thus became another in a line of regulatory failures by the agency, at least in the minds of the public and of politicians.

- The stock option scandals (backdating, spring loading, bullet dodging).$^{70}$ Ultimately, the SEC brought 70 or so prosecutions for failures to disclose these practices. ${ }^{71}$ Overall, however, nearly 300 publicly held corporations engaged in these and similar practices. Rather than the SEC, the plaintiffs' bar pulled the laboring oar, bringing derivative actions against companies and the directors who had permitted the practices to occur. ${ }^{72}$

- The mutual fund "shelf space" scandals. Trusted broker-dealers such as Edward D. Jones \& Co., were found to have betrayed the trust their customers historically have placed in them. These retail brokerage institutions caused their organizations' registered representatives to recommend purchase of a select group of mutual funds based not upon what might be best or suitable for their customers and their needs. Rather, in return for secret payments and other benefits, the parent broker-dealer organizations limited registered representatives in what was available and what they readily could recommend. The California Attorney General, and not the SEC, led the unearthing and later prosecution of these illicit shelf space $_{\text {practices. }}{ }^{73}$

70. Ryan v. Gifford, 918 A.2d 341, 345 (Del. Ch. 2007), describes backdating, a practice through which corporate officers backdated stock options to a date on which the market price was significantly lower so that the exercise or "strike" price would be lower and the profits correspondingly higher when corporate officers, principally CEOs, exercised those options. In re Tyson Foods, Inc., Consol. S'holder Litig., 919 A.2d 563, 572 (Del. Ch. 2007), describes spring loading, a practice through which stock option committees time the grant of options to corporate executives - typically, before public announcements of positive developments likely to result in significant increases in the price of the underlying stock. Bulletdodging occurs when those in control, sensing that the market has overreacted to negative news and unduly depressed the company's share price, quickly grant options to corporate executives, who thereafter have an inordinately low strike price for the options. Id.

71. See, e.g., Katz, supra note 40 , at 489.

72. See, e.g., Douglas M. Branson et al., Business Enterprises: Legal Structures, Governance, and Policy 438-43, 468 (2009).

73. See, e.g., Langevoort, supra note 53, at 439. 
- Bonus and executive compensation scandals. The SEC misfired badly, and incurred the wrath of a prominent federal judge, in its tepid prosecution of Bank of America in the \$3.6 billion Merrill Lynch bonus coverup. ${ }^{74}$ The Attorney General of New York, Andrew Cuomo, not the SEC, undertook a plenary and meaningful investigation of the matter. ${ }^{75} \mathrm{He}$ marched onward after Judge Jed Rakoff and the national media publicly called the SEC to account, further highlighting the SEC's failures. ${ }^{76}$

- The never-ending parade of Ponzi schemes, each seemingly larger than the last. Bernard Madoff stole approximately $\$ 15$ billion (not the $\$ 65$ billion the press has fixated upon) from his investment adviser clients. ${ }^{77}$ Over the years, the SEC received at least six tips that Madoff could not have achieved the financial results he claimed to have achieved or that he must have in some way been engaged in a fraudulent scheme. Yet the SEC did nothing.

Charitably, the SEC staff's failures are understandable. That anyone, and in particular former NASDAQ president Bernard Madoff, could have pulled off such a large fraud stretching over so many years, is far-fetched; and, indeed, it is equally far-fetched that he wouldn't have been caught, if not by the SEC, then another regulator or even a client. That no one caught Madoff at his game is, among other things, testimony not only to gullibility but also to affinity fraud. ${ }^{78}$

Other large far-fetched schemes also had come to light before the SEC had demonstrated even an inkling. R. Allen Stanford ran a high yield investment business that garnered over $\$ 7$ billion in investors' capital. Neither the SEC nor the applicable self-regulatory

74. See supra note 9 .

75. See Liz Rappaport, Dan Fitzpatrick \& Joann S. Lublin, Cuomo Calls in 5 BofA Directors, WALL ST. J., Sept. 17, 2009, at C3.

76. See Lewis's Retirement at Bank of America Will Not Affect Investigation, Cuomo Says, $41 \mathrm{Sec}$. Reg. \& L. Rep. (BNA), at 1834 (Oct. 5, 2009).

77. See, e.g., Edward J. Epstein, Confidence Man, Wall St. J., Aug. 15, 2009, at W8 (total loss estimated to be $\$ 15$ billion; receiver is attempting to recover $\$ 13.7$ billion via eight lawsuits).

78. Investors whom affinity fraud schemes have bilked typically are motivated, at least in part, by characteristics they share with the promoter (same race, same religion, same club, same church). Madoff "hawked his investment fund to a largely Jewish clientele... . Madoff became known as the 'Jewish T-bill,' as in risk-free." Andrea Sachs, Bernie Madoff_Publisher's Best Friend?, Time, Aug. 17, 2009, at 61; "The buying people did more research on buying a car than they did on the man who handled their money." Id. (quoting Erin Arvedlund, Too Good to Be True: The Rise and Fall of Bernie Madoff (2009)). 
organizations heeded warnings, tips, or other indications of what Stanford may have been doing. ${ }^{79}$

Not only has the SEC failed to detect or heed warnings and tips about many of these Ponzi schemes, the Commission and its staff have permitted other, lesser regulators to steal a march on the SEC in prosecuting those responsible for these massive frauds ${ }^{80} \mathrm{~A}$ chronicler of the Madoff episode describes recent years as "one of the most dysfunctional and inept periods in the Commission's history." $" 81$

- The newest investment scandals: the pay-to-play allegations. CalPERS, the largest public employee pension plan, paid \$50 million to a middleman (also a former director) to funnel investment proposals to it. ${ }^{82}$ These allegations shed further light on the practices of an industry previously in the netherworld, which earned lucrative fees for presenting investment opportunities to hedge funds, private equity firms, and pension plans such as CalPERS. Once again, the SEC was not among the first of the fire trucks to arrive at the scene. Andrew Cuomo, the Attorney General of New York, prosecuted the first cases, not the SEC. ${ }^{83}$

\section{CONCLUSION}

The SEC is moving in the correct direction. By flattening its organizational structure, eliminating middle management layers, and pushing authority down to or toward the front lines, the agency is making itself fleetfooted, imparting a sense of increased urgency to its enforcement effort. With proposals for a chief operating officer (COO), the Commission may come more to replicate the management structure of many large business

79. See, e.g., FINRA Publishes Report Showing Inadequate Handling of Stanford Complaints, 41 Sec. Reg. \& L. Rep. (BNA), at 1817 (Oct. 5, 2009).

80. See, e.g., California AG Sues Investment Adviser Who Allegedly Funneled Money to Madoff, 41 Sec. Reg. \& L. Rep. (BNA), at 1795 (Sept. 28, 2009).

81. Sachs, supra note 78, at 61 (quoting Erin Arvedlund, Too Good to Be True: The Rise And FALl of BerNiE MAdOFF (2009)). The Madoff fraud, and in part the SEC's failures therein, have already been the subject of three books. In addition to ARVEDLUnd, supra note 78, they include ANDREW Kirtzman, Betrayal (2009) and Jerry Oppenheimer, Madoff with the Money (2009).

82. Craig Karmin \& Peter Lattman, CalPERS Rocked by “Pay to Play, ”WALl ST. J., Oct. 15, 2009, at A1 (reporting on payments to Al Villalobos and Arvco Financial Ventures, LLC).

83. See Two Plead Guilty in N.Y. Probe Into Corrupt "Pay to Play" Practices, $41 \mathrm{Sec}$. Reg. \& L. Rep. (BNA), at 1872 (Oct. 12, 2009); see also Karmin \& Lattman, supra note 82. 
organizations. On the other hand, the Commission must remain wary of any trend, or renewed trek, toward über regulation. At least as matters now stand, such a trek would do more harm than good in the securities law enforcement area.

One further step might involve putting the fire truck nearer where the fire is likely to be. In other words, the Commission should give thought to a significant increase in resources and personnel for the New York Regional Office. Alternatively, the SEC might locate a sizeable strike force of attorneys, investigators, and staff in New York City, as the Commission once did in Salt Lake City. Putting sizeable regulatory forces a heartbeat away from Wall Street and the financial community might decrease or eliminate altogether the persistent time lag that exists between credible rumors and SEC action. It would put sets of knowledgeable ears close to the ground, creating and reinforcing the sense of urgency Chairperson Schapiro and other of the commissioners want to instill.

Is such a bold move akin to use of a meat clever when the circumstances call for a scalpel? Mr. Justice Breyer has written that "[m]odesty is desirable in one's approach to regulation." ${ }^{" 4}$ With regard to the SEC, Professor Adam Pritchard writes: "Scandal driven reform . . . has been a recurring pattern in securities markets .... [C]risis, however, does not create the ideal environment for developing balanced, cost effective policy interventions." 85 Over-regulation decreases American competitiveness. Reform advocates should prefer a "light touch," especially in comparison to the bludgeon of allocated resources this essay suggests. ${ }^{86}$

How to sort this out? In favor of the bludgeon approach, most of us avoid risk. On the spectrum of things, though, some of us can tolerate more or, indeed, much more risk. The latter may be termed "risk preferrers." Others of us can tolerate much less risk. This group can be labeled, again on the scale of things, "risk avoiders." Studies of the economics of crime and punishment by Nobel Laureate Gary Becker, ${ }^{87}$ and of antitrust civil and criminal sanctions by economists William Breit and Kenneth Elzinga ${ }^{88}$ demonstrate that the

\footnotetext{
84. Stephen Breyer, Regulation and Its Reform 184 (1982).

85. 85 A.C. Pritchard, The SEC at 70: Time for Retirement?, 80 Notre Dame L. Rev. 1073, 1081

86. See, e.g., Robert W. Hahn \& John A. Hird, The Costs and Benefits of Regulation: Review and Synthesis, 8 YAle J. on REg. 233, 258 (1991).

87. See generally Gary S. Becker, Crime and Punishment: An Economic Approach, 76 J. PoL. ECON. 169 (1968).

88. See, e.g., William Breit \& Kenneth G. Elzinga, Antitrust Penalties and Attitudes Toward Risk: An Economic Analysis, 86 HARV. L. ReV. 693 (1973).
} (2005). 
severity of punishment (20-year sentences, large fines) best deters the riskavoiding white collar defendant (an accountant, a banker, corporate directors). By contrast, the probability of detection rather than the severity of punishment deters the risk preferrer. Numbers of police on the beat deters more the criminal who sticks up gasoline stations at gun point. The possibility of a lengthy stretch of jail time barely enters the holdup artist's head.

Wall Street just went through an epoch of extreme risk. Leverage ratios (debt to invested capital) rose to 34 or higher at Lehman Brothers and Bear Stearns, to 32 at Merrill Lynch, and 100 to 1 at Long Term Capital Management, when at the typical retail or manufacturing company the ratio of loans to invested capital is approximately decimal .65. Can it be that individuals we have always thought of as risk avoiders (mangers of many of our largest financial institutions) are more like the "guys" who stick up gas stations on a Saturday night? That is, even though many of them wear shirts with white collars, the denizens of Wall Street are, on the scale of things, risk preferrers. If so, not severity of punishment but the probability of detection, greater numbers of SEC "cops" on the beat, will deter them from the practices we have witnessed over the last several years.

Perhaps now is the time for the General Services Administration (GSA) to seek out a midsize office building in midtown or downtown Manhattan. The reason? To house a newly installed posse of SEC enforcement staff. 